연구논문

해양에너지 복합발전단지의 경제적 타당성 분석에 관한 시론적 연구

이용길 ${ }^{1) *} \cdot$ 고진환 ${ }^{2)} \cdot$ 박우선 $^{3)}$

\title{
An Exploratory Study on the Analysis of the Economic Feasibility of an Ocean Energy Complex
}

\author{
Yong-Gil Lee*, Jin Hwan Ko and Woo-Sun Park
}

\begin{abstract}
This paper suggests an empirical results on economic evaluation of an ocean energy facility of complex generation. An ocean energy facility will be more important in the future, particularly such as in Korea with narrow territory. Types of complex generation will play more important roles in energy mix for their efficiency of energy generation. This research counts for both direct and indirect benefits of an ocean energy facility of complex generation. Consequently, under certain conditions, an ocean energy facility of complex generation seems to achieve economic feasibility.
\end{abstract}

Key words : Complex generation, Ocean energy, Economic evaluation

요 약 : 본 연구에서는 앞으로 중요성이 더욱 부각될 수 있는 해양에너지 복합발전단지 사업의 경제적 타당성 을 평가하였다. 해양에너지 복합발전단지 사업의 경제적 타당성을 평가하기 위해서 합리적인 분석기간 설정, 비용과 편익 추정 등을 수행하였다. 해양에너지 복합발전단지 사업은 적정 규모의 에너지 공급, 고부가물질의 창출 등의 조건을 충족시킬 경우, 경제적 타당성을 확보할 것으로 평가되었다. 본 사업의 경제적 편익은 직접적 인 경제적 편익 이외에 추가적으로 예상되어지는 간접적 편익들로 인해 도출된 수치보다 더 큰 편익을 나타낼 것으로 보이며, 실물옵션(Real Option) 등의 접근법을 통해 추가적인 경제성 평가가 가능할 것으로 보인다.

주요어 : 복합발전단지, 해양에너지, 경제성평가

\section{서 론}

에너지공급의 원천으로서 해양에너지에 대한 관심이 증대하고 있으며 우리나라의 서남동해안은 조력·조류· 파력 발전의 적지로 인식되기도 한다. 해양에너지는 온 실가스 배출을 줄일 수 있는 청정에너지임과 동시에 재 생가능한 무한한 에너지원이라는 점에서 대체 에너지원 으로 각광받고 있다. 이렇게 삼면이 바다로 둘러싸인 우 리나라의 지형조건은 해양에너지 개발의 선진국인 영국, 덴마크, 독일 등 해양에너지 선진국과 함께 세계적인 해

\section{3년 3월 19일 접수, 2013년 6월 11일 심사완료}

2013년 6월 13일 게재확정

1) 인하대학교 에너지자원공학과 조교수

2) 한국해양과학기술원 연안개발- 에너지연구부 선임연구원

3) 한국해양과학기술원 연안개발- 에너지연구부 책임연구원

*Corresponding Author(이용길)

E-mail; leedomingo@inha.ac.kr

Address; Department of Energy Resources Engineering, Inha University, Incheon, Seoul, Korea
양에너지 부존지역으로 개발 여건이 우수하며 해양에너 지 개발의 상당한 잠재력을 가지고 있다. 특히 서해안은 조석 간만의 차이가 크고 수심도 얕을 뿐 아니라 해안선 의 굴곡이 심해 조력발전의 좋은 입지를 보이고 있기도 하다. 이에 따라. 정부와 민간은 우리나라의 연안 및 해 양의 적절한 부지를 찾아 해상풍력, 조력, 파력, 복합발 전 등의 에너지공급을 위한 다양한 시도를 하고 있다.

Ko 등(2011)은, 개별적인 에너지원에 대한 발전시스 템의 건설의 경우, 발전 구조물의 해상공사에 따른 고비 용으로 인해 경제성 확보가 어려운 것으로 보았다. 또한 연안이나 에너지 소비 지역과의 거리가 먼 경우, 송전선 로 구축 등에 많은 비용이 소요되고, 전력생산이 불규칙 적이며(단속성과 간헐성), 따라서 전력생산을 계획하기 힘들어 고품질의 전력생산이 어렵다고 보았다. 이러한 개별 에너지원 발전시스템의 낮은 경제성 및 전력품질 문제를 극복하기 위해서는 각 해양에너지원별 요소기술 들을 융복합하여 복합발전 및 다양한 형태의 복합발전 단지 기술 개발이 필요하다. 또한, 에너지 저장 및 활용 
기술을 이용하여 신재생에너지의 불규칙 발전 문제를 극 복한다면, 복합발전 분야는 에너지 생산 효율성 확보는 물론 또 다른 부가가치를 창출해 낼 수 있는 신사업분야 가 될 수 있을 것으로 전망된다.

그러나 해양에너지 개발은 아직도 1) 경제성이 현저히 미흡하다는 점과 2) 지역생태계 보존 및 지역 주민의 삶 의 기반 훼손 등과 관련하여 많은 문제점과 갈등요소를 배태하고 있다. 본 논문은 2)의 이슈에 대해서는 해결되 어야 할 과제로 남겨 놓은 체, 1)의 이슈에 대하여 시범 적으로 경제성평가를 수행해 보는데 그 목적이 있다. 서 해안의 한 지점에 신재생에너지 분야인 풍력과 태양광, 바이오의 3 개의 복합발전을 활용한 발전단지에 대한 경 제성평가를 수행해 보도록 한다. 본 연구에서는 국내 해 양에너지 복합발전단지에 관한 분석기간, 비용추정, 비 용분석, 편익추정, 경제성 분석을 통해 해양 에너지 복합 발전단지의 경제성 타당성 분석과 향후 다양한 기대효과 에 대하여 제시하고자 한다.

\section{경제성분석의 주요 전제}

연구개발 사업의 경제적 타당성을 평가하기 위해서는 사업 수행기간이 아니라 해당 사업의 효과가 몇 년이나 지속될 것인지를 의미하는 분석기간, 즉 비용편익 분석 의 대상 기간을 결정해야 한다. 또한 경제적 타당성은 분 석 기간에 걸쳐 균일하게 효과가 발생하기도 하고, 비 균 일하게 효과가 발생하기도 한다. 이러한 부분에 대해서 는 적절한 가정을 토대로 모형을 설계해야 한다. 분석 기 간을 너무 짧게 잡으면 사업의 효과가 제대로 반영되지 못하는 문제점이 발생하고, 반대로 너무 길게 잡으면 비 용 또는 편익 측정에서의 불확실성(Uncertainty)이 너무 커져 결과 자체를 신뢰하기 어렵게 된다. 분석 기간에 대 하여 최적으로 설정하는 것 역시 연구의 중요한 이슈이 며, 해당 기술 분야의 $\mathrm{R} \& \mathrm{D}$ 전문가, 사업전문가 등의 의 견을 토대로 적절하게 분석 기간을 설정해야 할 것이다. 따라서 합리적인 범위 내에서 분석기간을 적절하게 설정 하는 것이 중요한 문제로 연구개발 사업 기간과 연구개 발 사업 기간이 종료된 후 편익이 발생하는 기간으로 구 분하여 설정해야 한다.

연구개발 사업 기간은 2014년 2016년의 3년간으로 계획하였다. 20억(2014년), 30억(2015년), 50억(2016년) 등 100 억의 R\&D투자를 계획하고 있으며, 이외에 시범 시험(Pilot Test) 비용은 400억 안팎 추가 투자(20172018년)를 예상하였다. 이러한 가정은 8년마다 50억 규 모의 설비 재투자와 연간 운영비용을 10.7 억원으로 예측 한 바에 기인한다.
풍력, 태양광, 바이오의 에너지 정산단가는 모두 $1 \mathrm{KWH}$ 에 대하여 150 원을 사용하였고, 신재생 및 대체에너지의 정산단가는 기술혁신 및 원가절감 등의 효과로 그 가격 이 하락하리라는 가정과 에너지 가격의 전반적인 상승에 따른 상승 요인이 혼재되어 있다. 따라서 가장 최근의 정 산단가의 평균값인 150 원을 우선적으로 사용하였지만, 신재생 및 대체에너지의 정산단가에 대한 변동폭에 대한 가정을 도입함으로써, 불확실성을 경제성 분석에 반영할 수 있는 실물옵션을 활용한 경제성 평가가 추가적으로 이루어져야 할 것으로 보인다. 바이오연료는 $8,750 \mathrm{kl} / \mathrm{year}$ 규모 생산을 예상하며, 고부가물질(클로로필, 피코시아 닌, 비타민 B12) 연간 시장 규모와 부가가치 추정 규모 는 $10 \mathrm{ha}$ 기준 8.85 조원 규모로 추산하였다(KIOST, 2011). 해양바이오에너지산업의 고부가물질 창출 부분에 대한 편익의 추정결과는 Table 1 과 같다.

이산화탄소 연간 회수량은 21,000 톤/year로 가정하였 으며, 이산화탄소 1 톤 회수당 편익은 최근의 시장 동향 을 고려하여 20,000 원으로 산정하였다. 탄소배출권 가격 에 대해서도 변동폭을 도입한 실물옵션을 이용한 경제성 분석을 행해볼 필요가 있을 것이다.

Lee(2011)에서는 2000년부터 2009년까지 미국등록특 허 155 만여 건의 인용정보를 이용해 국제 특허분류(IPC; International Patent Classification) 클래스별 기술 수명 주기 중위수(median)를 산정하여 제시한 바, 이에 근거 하여 편익 발생기간을 결정하는 것이 논리적으로 근거를 가진다. IPC 분류 중 '기계요소 또는 단위 : 기계 또는 장치의 효율적 기능을 발휘하고 유지하기 위한 일반적인 수단(F16)'이 본 사업과 가장 밀접하며 이에 해당하는 기술수명주기는 13 년으로 산출되기에 이 값을 적용할 수 있다. 기술수명주기는 R\&D 완료 후, 가산되며, 이러 한 기술수명주기를 고려하여 플랜트의 종합적인 수명이 결정될 수 있다.

동 연구사업의 목표가 에너지 플랜트의 건설이며, 중간 대규모의 투자를 고려하여 편익발생기간을 25 년으로 산 정하는 대신에 중간에 8 년마다 두 번에 걸쳐 50 억 규모 의 설비 재투자가 이루어진다고 가정한다. 즉, 사업완료 후 2019년 2043년 동안, 즉 25년간 편익이 발생한다고 가정해 볼 수 있다. 여기에 대한 경제성 분석 대상기간은 사업기간과 기술수명주기를 합친 2014년부터 2043년까 지의 30 년간으로 한다. 따라서 기준년도는 경제적 타당 성 평가에서 편익과 비용이 제각기 다른 시점에서 발생되 므로, 사회적 할인율을 이용하여 비교 가능한 동일시점의 가치로 일치시켜야 한다. 따라서 본 연구에서는 비용-편 익분석의 기준 시점을 연구진행 시점인 전년도 말에 해당 하는 2011년 12월말 기준으로 통일하여 평가하였다. 


\section{비용 추정}

\section{비용의 구성}

편익을 발생시키기 위한 총비용은 사업비, 예비비, 인 건비, 시설유지관리, 장비재투자비, 잔존가치로 구성된 다. 모듈 2개(풍력 2기, 생산소 2기, 수상태양광 2기)에 대한 비용 추정은 아래 표와 같은데, 향후, 단지(모듈 20 개)로 사업화 할 때는 R\&D 비용은 없고 비용 $\times 10$ 배가 들어갈 것으로 예상된다. 본 비용은 국내·외(새만금 등) 에서 추진하고 했던 복합발전 설비의 스펙을 토대로 추 산되었다. 구체적인 비용은 Table 2와 같다.

\section{총비용의 추정}

이를 토대로, 경제성분석 대상기간에 발생하는 총 비 용은 Table 3 과 같다.

\section{편익 추정}

\section{편익 추정의 전제조건}

편익 추정 과정에서 적용한 몇 가지 전제 조건에 대해 검토한 결과는 Table 4 와 같다. R\&D 기여도는 동 사업 에서 $\mathrm{R} \& \mathrm{D}$ 의 기여도 부분을 추출한 수치이다. 통상, $28.1 \%$ 를 사용한다. 상용화 성공률은 해당 분야의 $\mathrm{R} \& \mathrm{D}$ 혹은 기술혁신의 상용화 성공률서 KIAT의 $48.74 \%$ 를 원 용하였다. 프로젝트 기여율은 국가 R\&D(민간부문 포함) 에서 동 사업이 차지하게 될 비율을 예상한 수치이다. 부 가가치율은 한국은행의 산업연관표에서 해당 분야의 부 가가치율을 원용하였다.

\section{플랜트 세부 기술 스펙 개요}

플랜트 세부 기술에 대한 스펙은 크게 4 가지로 나누어 볼 수 있는데 첫 번째로 복합발전단지 모형 및 적정규모

Table 1. Estimation of benefits of high quality materials from ocean bio-energy industry in Korea (Unit: million won)

\begin{tabular}{|c|c|c|c|c|}
\hline Order & Year & Market size expected & Benefit & Present value \\
\hline 1 & 2015 & $8,851,800$ & 44,753 & 34,242 \\
\hline 2 & 2016 & $8,851,800$ & 44,753 & 32,457 \\
\hline 3 & 2017 & $8,851,800$ & 44,753 & 30,765 \\
\hline 4 & 2018 & $8,851,800$ & 44,753 & 29,161 \\
\hline 5 & 2019 & $8,851,800$ & 44,753 & 27,641 \\
\hline 6 & 2020 & $8,851,800$ & 44,753 & 26,200 \\
\hline 7 & 2021 & $8,851,800$ & 44,753 & 24,834 \\
\hline 8 & 2022 & $8,851,800$ & 44,753 & 23,539 \\
\hline 9 & 2023 & $8,851,800$ & 44,753 & 22,312 \\
\hline 10 & 2024 & $8,851,800$ & 44,753 & 21,149 \\
\hline 11 & 2025 & $8,851,800$ & 44,753 & 20,047 \\
\hline 12 & 2026 & $8,851,800$ & 44,753 & 19,001 \\
\hline 13 & 2027 & $8,851,800$ & 44,753 & 18,011 \\
\hline 14 & 2028 & $8,851,800$ & 44,753 & 17,072 \\
\hline 15 & 2029 & $8,851,800$ & 44,753 & 16,182 \\
\hline 16 & 2030 & $8,851,800$ & 44,753 & 15,338 \\
\hline 17 & 2031 & $8,851,800$ & 44,753 & 14,539 \\
\hline 18 & 2032 & $8,851,800$ & 44,753 & 13,781 \\
\hline 19 & 2033 & $8,851,800$ & 44,753 & 13,062 \\
\hline 20 & 2034 & $8,851,800$ & 44,753 & 12,381 \\
\hline 21 & 2035 & $8,851,800$ & 44,753 & 11,736 \\
\hline 22 & 2036 & $8,851,800$ & 44,753 & 11,124 \\
\hline 23 & 2037 & $8,851,800$ & 44,753 & 10,544 \\
\hline 24 & 2038 & $8,851,800$ & 44,753 & 9,994 \\
\hline 25 & 2039 & $8,851,800$ & 44,753 & 9,473 \\
\hline \multicolumn{2}{|c|}{ Total } & $221,295,000$ & $1,118,836$ & 484,588 \\
\hline
\end{tabular}


부터 살펴보면 다음과 같다.

- $100 \mathrm{~m} \times 100 \mathrm{~m}$ (1ha) 1 모듈 (Module), 두께 2-3 $\mathrm{m}$ 부상방식
- $720 \mathrm{KL} / \mathrm{yr}$ 미세조류 바이오연료 원료생산플랜트

1 유닛(Unit)

- 2MW급 해상풍력 1 유닛

- $100 \mathrm{KW}$ 급 수상태양광 1 유닛

Table 2. Construction and estimation of total cost

(Unit: million won)

\begin{tabular}{lcc}
\hline \hline \multicolumn{1}{c}{ Classification } & Cost & Contents \\
\hline 1. Design & 759 & (1)+(2) \\
\hline (1) Design & 459 & $1.34 \%$ of total cost \\
\hline (2) Assessment & 300 & Environmental assessment and so forth \\
\hline 2. Floating body & 9,756 & (1)+(2)+(3)+(4) \\
\hline $\begin{array}{l}\text { (1) Concrete body } \\
\text { (2Modules) }\end{array}$ & 2,910 & $\begin{array}{c}\text { Concrete Module } \\
\text { Module size: } 100 \mathrm{~m} \times 50 \mathrm{~m} \times 2 \mathrm{~m}\end{array}$ \\
& & Unit cost per 1 Module: 1,452 \\
\hline (2) Module linker & 2,200 & $\begin{array}{c}\text { 2 linkers between Modules } \\
\text { Unit cost per linker: } 550\end{array}$ \\
\hline
\end{tabular}

(3) Mooring System

(2Modules)

Vertically movement

Fixed by horizontal power

Unit cost: 1,510

1 Mooring System per Module

\begin{tabular}{|c|c|c|}
\hline (4) Secondary work & 1,626 & $20 \%$ of $(1)+(2)+(3)$ \\
\hline 3. Generator & 15,900 & Based on Saemanguem facility \\
\hline \multirow{2}{*}{ (1) Wind power } & \multirow{2}{*}{9,700} & 4,850 per generator \\
\hline & & 1generator per Module \\
\hline \multirow{2}{*}{ (2) Construction } & \multirow{2}{*}{5,500} & 2,750 per generator \\
\hline & & Other constructions \\
\hline \multirow{2}{*}{ (3) Facilities } & \multirow{2}{*}{700} & 350 per generator \\
\hline & & Other constructions \\
\hline 4. Buildings & 720 & (1) $+(2)$ \\
\hline \multirow{2}{*}{ (2) Management } & \multirow{2}{*}{720} & $10 \mathrm{~m} \times 10 \mathrm{~m} \times 4 \mathrm{~m}$ \\
\hline & & $0.180 / \mathrm{m}^{2}$ \\
\hline 5. Operation & 1,055 & (1)+(2) \\
\hline (1) Operation & 528 & $2 \%$ of $(2+3+4)$ \\
\hline (2) Maintenance & 528 & $2 \%$ of $(2+3+4)$ \\
\hline Construction & 26,376 & $(2+3+4)$ \\
\hline Other costs & 7,913 & $30 \%$ of $(2+3+4)$ \\
\hline Total cost & 34,289 & Construction + Other costs \\
\hline $\begin{array}{l}\text { Total cost of project without } \\
\text { solar and fuel cell }\end{array}$ & 36,103 & $\begin{array}{c}\text { Total cost }+ \text { Design }(1) \\
+ \text { Operation }(5)\end{array}$ \\
\hline Solar & 3,000 & Solar + Other costs \\
\hline Fuel cell & 897 & Fuel cell + Other costs \\
\hline $\begin{array}{l}\text { Total cost of project with solar } \\
\text { and fuel cell }\end{array}$ & 40,000 & Total cost with solar and fuel cell \\
\hline
\end{tabular}


Table 3. Estimation of total cost considering time span

(Unit: 100million won)

\begin{tabular}{|c|c|c|c|c|c|c|c|c|}
\hline Year & R\&D & $\begin{array}{c}\text { Facility } \\
\text { investment }\end{array}$ & Reserve & Operation & Re-investment & $\begin{array}{c}\text { Salvage } \\
\text { value }\end{array}$ & Cost & Present cost \\
\hline 2014 & 20 & & 0.2 & & & & 20.2 & 18.1 \\
\hline 2015 & 30 & & 0.3 & & & & 30.3 & 25.8 \\
\hline 2016 & 50 & & 0.5 & & & & 50.5 & 40.8 \\
\hline 2017 & & 200 & & & & & 200 & 153.0 \\
\hline 2018 & & 200 & & & & & 200 & 145.0 \\
\hline 2019 & & & & 10.7 & & & 10.7 & 7.4 \\
\hline 2020 & & & & 10.7 & & & 10.7 & 7.0 \\
\hline 2021 & & & & 10.7 & & & 10.7 & 6.6 \\
\hline 2022 & & & & 10.7 & & & 10.7 & 6.3 \\
\hline 2023 & & & & 10.7 & & & 10.7 & 5.9 \\
\hline 2024 & & & & 10.7 & & & 10.7 & 5.6 \\
\hline 2025 & & & & 10.7 & & & 10.7 & 5.3 \\
\hline 2026 & & & & 10.7 & 80 & & 90.7 & 42.9 \\
\hline 2027 & & & & 10.7 & & & 10.7 & 4.8 \\
\hline 2028 & & & & 10.7 & & & 10.7 & 4.5 \\
\hline 2029 & & & & 10.7 & & & 10.7 & 4.3 \\
\hline 2030 & & & & 10.7 & & & 10.7 & 4.1 \\
\hline 2031 & & & & 10.7 & & & 10.7 & 3.9 \\
\hline 2032 & & & & 10.7 & & & 10.7 & 3.7 \\
\hline 2033 & & & & 10.7 & & & 10.7 & 3.5 \\
\hline 2034 & & & & 10.7 & 80 & & 90.7 & 27.9 \\
\hline 2035 & & & & 10.7 & & & 10.7 & 3.1 \\
\hline 2036 & & & & 10.7 & & & 10.7 & 3.0 \\
\hline 2037 & & & & 10.7 & & & 10.7 & 2.8 \\
\hline 2038 & & & & 10.7 & & & 10.7 & 2.7 \\
\hline 2039 & & & & 10.7 & & & 10.7 & 2.5 \\
\hline 2040 & & & & 10.7 & & & 10.7 & 2.4 \\
\hline 2041 & & & & 10.7 & & & 10.7 & 2.3 \\
\hline 2042 & & & & 10.7 & & & 10.7 & 2.1 \\
\hline 2043 & & & & 10.7 & & -30 & -19.3 & -3.7 \\
\hline Total & 100 & 400 & 1 & 256.8 & 160 & -30 & 898.5 & 543.6 \\
\hline
\end{tabular}

Table 4. Factors for estimation of benefits

\begin{tabular}{lcl}
\hline \multicolumn{1}{c}{ Criteria } & Value & \\
\hline Time span & 25 years & Life of energy plant \\
\hline Social discount rate & $5.5 \%$ & Reference value from KDI \\
\hline R\&D contribution & $28.1 \%$ & KDI: $10.9 \%$, or KISTEP: 28.1\%. Here KISTEP indicator used \\
\hline $\begin{array}{l}\text { Success rate of technological } \\
\text { commercialization }\end{array}$ & $48.74 \%$ & Reference from KIAT (Korea Institute of Advanced Technology) \\
\hline $\begin{array}{l}\text { Project contribution } \\
\text { Rate of added value }\end{array}$ & $15 \%$ & $\begin{array}{l}\text { Based on calculation, how much the portion of this project is among } \\
\text { national R\&D programs }\end{array}$ \\
\hline
\end{tabular}


두 번째로 플랜트 세부 기술 방식으로는 1 플랫폼-4 모듈(4 ha), 모듈 간극 0.5-1 m 힌지(hinge) 체결, 돌핀계 류 방식을 활용하고 있으며, 1 단지-5 플랫폼-20 모듈(20 $\mathrm{ha}$ 로 세부 내용은 다음과 같다.

- 미세조류 바이오 연료: 7,830 TOE/yr

- 약 $8,750 \mathrm{KL} / \mathrm{yr}$ 의 바이오디젤 생산

- 이산화탄소 21,000 톤 회수

- 고부가물질: $10 \mathrm{Ha}$ 기준 8.85 조원 규모의 고부가물 질이 창출된다고 가정함. 2 ha 기준 8 천억 정도의 시 장 규모 추정

세 번째로는 해상풍력발전(효율 $25 \%$ 기준)으로 40 $\mathrm{MW}$ 규모로 연간 약 18,200 가구에서 사용가능한 87,600 $\mathrm{MWh}$ 발전량이 추정되고 있으며, 7,534 TOE/yr 대체효 과를 가져올 것으로 보인다.

네 번째로는 수상 태양광(효율 $15 \%$ 기준)으로 $2 \mathrm{MW}$ 규 모로 연간 546가구에서 사용가능한 $2628 \mathrm{MWh}$ 의 발전 량이 추정되고 있으며, $226 \mathrm{TOE} / \mathrm{yr}$ 대체효과를 가져올 것으로 추정된다. 위 스펙을 에너지정산단가로 환산하여 직접 편익을 추정하도록 한다.

\section{정산단가 추정}

현재 신재생에너지발전의 정산단가는 계통한계가격(System Marginal Price; SMP)을 적용받고 있다. 즉, 신재생에너 지발전의 경우, 동 시간에 거래되는 전력의 가장 비싼 가 격을 책정해 주는데, 이는 신재생에너지발전이 여타발전 에 비해 경제성이 떨어지기 때문이다(Lee and Jeong, 2011).

계통한계가격이란 거래시간별로 일반발전기(원자력, 석탄 외의 발전기)의 전력량에 대해 적용하는 전략시장 가격(원 $/ \mathrm{kWh}$ 으로서, 비제약발전계획을 수립한 결과 시 간대별로 출력(output)이 할당된 발전기의 유효 발전가 격(변동비) 가운데 가장 높은 값으로 결정된다. 또한 기 저한계가격(Base Load Marginal Price)은 현행 원가반 영(CBP; Cost Based Price) 전력시장 체제에서 거래시 간별로 기저발전기(원자력, 석탄발전기)의 전력량에 적 용하는 전력시장가격(원 $/ \mathrm{kWh})$ 으로, 시간대별로 실제 전 력을 생산한 기저발전기 중에 중 변동비(유효발전가격) 가 가장 높은 발전기의 변동비로 결정된다. 발전부문에 있어서는 시장의 효율성 도입을 위해 많은 노력을 하고 있지만 전력요금은 여전히 국가 규제의 대상이 되고 있 다. 신재생에너지발전을 제외한 여타 발전소의 경우, 발 전소의 건설, 운영시간, 발전을 위한 연료비, 인건비 등 다양한 요소가 고려되어 적정 수준의 수익만이 보장되는 정산단가가 정해져 있으며, 시장가격이라고 부르는 계통
한계가격은 동 시간대에 발전하는 가장 정산단가가 높은 발전기의 정산단가가 된다.

유연탄발전의 정산단가는 거래일 계획발전 전력량정 산금(Scheduled Energy Price: SEP), 용량요금(Capacity Payment: CP), 계통보조금서비스 정산금(Ancillary Service Payment: ASP) 등의 합으로 정해진다. 거래시간별 계획 발전 전력량정산금(SEP)이란 각 시간대별로 미리 계획 된 발전량을 생산해서 송전함으로써 발전회사가 받아가 는 정산금(현 시점에서의 수요 공급과 관련 없음)을 말 한다. 용량요금 $(\mathrm{CP})$ 은 거래시간별 중앙급전발전기 공급 가능 용량에 적용되는 전력시장가격으로 발전설비에 대 하여 실제 발전 여부와 관계없이 미리 정해진 수준의 요 금을 지불하며 신규투자를 유인하기 위한 제도이다. CP 수준은 일반적으로 예비력 수준과 공급지장비용 수준에 따라 달라진다. 계통보조금서비스 정산금(ASP)은 전력 시장에서 거래되는 상품인 전기에너지의 가격(energy payment)외에 계통을 안정적으로 운영하기 위한 주파수 조정 예비력, 발전기 불시정지에 대한 예비력, 계통정전 시 복구를 위한 자체가동 기능 발전력 확보, 계통의 적정 전압조정에 필요한 무효전력확보 등을 위해 기여한 발전 기들에게 추가로 수요되는 비용에 대해 지급되는 보상금 을 말한다. 2001년부터 2009년까지 계통한계가격과 유 연탄 발전의 정산단가를 비교해 보면 50-80\% 수준이다.

풍력과 태양광과 같은 발전원의 경우에 있어서는 유연 탄 발전에 비해 운영상의 유연성이 크게 부족하여 발전 계획에 포함되지 않고 있는데, 전력부문에서는 발전단가 보다 안정적인 공급이 중요하다. 현 기술 수준에서 풍력 발전의 경우, LNG 발전에 비해 발전단가가 저렴하지만, 전력의 운영 측면 때문에 발전부문에서 중앙급전이 가능 한 화력발전을 더 선호한다. 이러한 문제가 해결되기 위 해서는 전력의 저장에 관한 문제가 해결되어야 하지만, 현 기술 수준에서는 이러한 문제를 해결하기가 어려운 현실이다.

본 분석에서 고려하고 있는 신재생에너지발전의 상당 부분을 풍력발전이 차지하고 있는데, 한국전력거래소의 평가 의견에 따르면, 전력시장에서 풍력발전의 경우 이 미 그리드 패리티(grid parity)1)에 도달한 것으로 보고

1) Grid Parity: 화석연료 발전단가와 신재생에너지 발전단가가 같아지는 시기를 말한다. 현재, 신재생에너지 발전단가가 화 석연료보다 월등히 높지만, 각국 정부의 신재생에너지 육성 정책과 기술 발전에 따라 비용이 낮아지게 되면 언젠가는 등 가(parity) 시점이 올 것이라는 전망이다. 현대경제연구원에 따르면, 2008 년 국내 전기 생산의 $1 \mathrm{kw}$ 당 발전정산단가가 68.9 원이므로, 특정 신재생에너지가 그리드 패리티에 도달 하기 위해서는 발전단가가 68.9 원 미만이어야 한다. 2008년 기준으로 국내 신재생에너지원별 발전단가를 추산하면, 바 
Table 5. System marginal contract price of renewables

(Unit: won)

\begin{tabular}{ccccccccccc}
\hline \hline Year & Bio gas & $\begin{array}{c}\text { By product } \\
\text { gas }\end{array}$ & $\begin{array}{c}\text { Small } \\
\text { hydro }\end{array}$ & $\begin{array}{c}\text { Land fill } \\
\text { gas }\end{array}$ & PV & Waste & Wind & Fuel cell & Ocean & Average \\
\hline 2012 & 150.6 & 91.6 & 152.4 & 151.1 & 160.9 & 150.7 & 173.9 & 150.4 & 148.1 & 114.5 \\
\hline 2011 & 123.5 & 88.6 & 123.2 & 124.4 & 130.7 & 123.8 & 143.1 & 124.5 & 134.0 & 102.1 \\
\hline 2010 & 115.6 & 92.1 & 115.3 & 115.1 & 124.9 & 114.0 & 124.3 & 114.2 & 117.6 & 105.2 \\
\hline 2009 & 97.9 & 103.3 & 94.0 & 104.2 & 103.7 & 96.3 & 107.8 & 102.0 & 126.2 & 103.7 \\
\hline 2008 & 127.3 & 132.0 & 115.6 & 121.3 & 136.9 & 122.6 & 126.7 & 146.9 & - & 127.3 \\
\hline 2007 & 78.6 & 86.4 & 80.3 & 84.2 & 86.7 & 81.0 & 83.7 & 82.0 & - & 84.6 \\
\hline 2006 & 84.8 & 84.9 & 75.3 & 78.6 & 82.4 & 76.7 & 79.0 & 84.7 & - & 81.1 \\
\hline 2005 & 53.5 & 64.4 & 58.5 & 59.7 & 63.4 & 61.3 & 63.2 & - & - & 62.4 \\
\hline 2004 & - & 59.2 & 52.9 & 54.5 & 58.5 & 53.7 & 55.7 & - & - & 57.5 \\
\hline 2003 & - & 54.3 & 48.2 & 47.9 & - & 49.5 & 51.7 & - & - & 52.4 \\
\hline 2002 & - & 48.0 & 45.1 & 46.0 & - & - & 49.4 & - & - & 45.6 \\
\hline 2001 & - & - & 48.0 & 54.4 & - & - & 50.0 & - & - & 50.3 \\
\hline
\end{tabular}

※ Source: www.kpx.or.kr/epsis/

있다. 현재 풍력발전의 발전차액은 $\mathrm{KWH}$ 당 107 원으로 최근 데이터를 보면, SMP가 발전차액을 넘어서는 경우 가 자주 발생한다. 이러한 경우에는 발전회사는 풍력발 전설비를 늘리는 것이 경제적으로 합리적일 수 있으나, 풍력발전의 경우, 발전계획에 의한 중앙급전이 불가능하 다는 치명적인 단점을 가지고 있다. 전력은 그 가격적인 측면보다 안정적인 공급이 중요한 특징이며, 따라서 오 히려 한계비용이 높은 $\mathrm{LNG}$, 등유 발전기 등의 설비를 확보하고 있는 실정이다. 신재생에너지 의무할당제도에 서는 각 발전자회사들에게 태양광발전의 설비용량을 별 도로 지정하고 있는데, 이는 경제성 분석에서 나타나는 경제성 격차 때문이다. 현 시점에서 태양광발전의 발전 원가가 다른 신재생에너지원에 비해 높다고 하더라도 기 술개발을 포기할 수 없고, 이를 위해 적정규모의 국내 시 장의 수요가 존재해야 하기 때문이다. 태양광과 풍력발 전의 경우에는 원자력이나 화력 발전에 비해 수십 배 이 상의 면적이 필요한데, 이러한 경우, 미래의 발전소 건설 비는 지가에 영향을 많이 받게 된다. 기존의 발전소들이 가장 경제성이 있는 지역에 건설되고, 향후 신재생에너 지공급화 의무제도(RPS 제도)2)가 보다 본격적으로 시

이오매스(69원)가 가장 싸고, 조력(77원), 연료전지(168원), 풍력(170원), 그리고 태양광(570원)의 순서로 비싸다(Hyundai Research Institute, 2009).

2) 신재생에너지 공급의무화 제도(Renewable Portfolio Standard 제도): 지식경제부(구 산업통상자원부)에 따르면 신재생에너 지 공급의무화 제도(RPS 제도)는 일정 규모 이상의 발전설
행된다면 기존의 지가보다 더욱 비싼 지역에 건설될 수 밖에 없을 것이다.

신재생에너지의 정산단가는 Table 5 와 같으며, 동 분 석에서는 풍력, 태양광, 바이오에너지에 대하여 $1 \mathrm{KWH}$ 당 150 원을 사용하였다(Table 5). ${ }^{3)}$ 이는 2012년 풍력,

비를 보유한 발전사업자에게 총 발전량의 일정량 이상을 신 재생에너지로 생산한 전력을 공급토록 의무화한 제도이다. 발전사에게 직접 신재생에너지의 공급을 의무화하므로 보급 효과를 배양 시킬 수 있고 정부의 재정부담 완화시킬 수 있 으며, 조기 산업화, 시장 확대 등을 통한 산업경쟁력 강화 및 일자리창출을 기대할 수 있다(MKE and CNRE, 2011).

3) 지식경제부에 따르면 지난 2012년 2월 SMP는 전년 동월 $\mathrm{KWh}$ 당 123.5 원에서 $29.5 \%$ 상승한 159.9 원을 기록했으며, 같은 기간 정산단가도 전년 $\mathrm{KWh}$ 당 76.1 원에서 100.2 원으 로 상승하였다. 특히 지난 3 월의 SMP는 전년 동월의 123 원 에서 175.7 원으로 $42.8 \%$ 로 급상승하였다. 이 같은 SMP 상 승은 유연탄이나 $\mathrm{LNG}$ 의 열량단가 오름세에 따른 것으로 보 고 있지만 이들 발전연료의 Gcal당 열량단가는 전년 2월 대 비 $\mathrm{LNG}$ 는 $17.73 \%$ (7만1943원), 유류는 $37.59 \%$ (9만8693 원), 유연탄은 $32.58 \%$ (2만 2573 원) 등으로 상대적으로 상승 폭이 적은 $\mathrm{LNG}$ 가 유리하지만 다른 화석연료는 상승폭이 매 우 크다는 것을 알 수 있다. $\mathrm{LNG}$ 를 이용할 경우 한국가스공 사를 통하여 안정적이고 신속하게 연료수급이 가능하고 발 전소건설 비용도 적어 투자비 회수가 빠른 특징을 갖고 있 다. 연료 가격 면에서는 석탄단가가 저렴하고 수명도 20-30 년이 되기 때문에 장기적이고 안정적인 이익을 얻을 수 있 어서 최대의 투자처로 각광을 받고 있다. 지난 2 월 기준으로 석탄화력 설비용량은 $31.7 \%$ 인 반면 발전량은 $38.3 \%$ 인 것을 보면 기저부하로 지속적인 운전이 되고 있는 것을 알 수 있 다(Moon, 2012). 
태양광, Bio gas의 정산단가에 근접한 수치를 사용하였 다. 3 가지의 전력발전원(풍력, 태양광, 바이오에너지)의 발전량은 시간에 따라 다른 패턴을 보일 것이며, 시간대 에 따라 다른 정산가격을 적용하는 것이 타당하나, 본 연 구에서는 연간 평균 발전량을 산출하여 편익을 계산하고 자 하였다.

\section{이산화탄소 저감 편익}

탄소배출권은 이미 국제 시장에서 활발히 거래가 이루 어지고 있다. 유럽에서 가장 활발한 거래가 이루어지고 있으며, 거래 가격을 분석해 보면, €5-€20/Ton $\mathrm{CO}_{2}$ 수 준이다. 본 연구에서는 탄소배출권에 대한 가치를 보수 적으로 적용하여, 이산화탄소 1 톤당 20,000 원으로 가정 하여 분석을 진행하였다. 탄소배출권의 최근 시세 및 장 기전망치가 훨씬 더 하락할 가능성이 있다. 하지만, 동사 업의 편익발생기간이 2043 년까지 중장기에 걸친 기간이 라는 점과 탄소배출권의 가격이 2008년에 비하여 현재 $10 \%$ 수준으로 급락한 점 등을 감안하여, 장기가격을 위 와 같이 설정하였다.

\section{경제성 분석}

\section{경제성분석 방법}

경제성 분석은 편익/비용 비율(B/C ratio), 순현재가치 (NPV), 내부수익률(IRR) 등의 계산을 통하여 사업의 경 제성을 파악하는 과정이며, 경제성 분석에 사용된 각종 추정치의 오차를 보완하기 위하여 주요 변수의 변화가 경제성에 미치는 영향에 대한 민감도 분석을 수행할 수 있다.

편익/비용 비율(B/C ratio)은 개별 대안사업별로 편익 의 현재가치를 비용의 현재가치로 나눈 값이 가장 큰 대 안을 선택하는 방법이다. 사업의 비용, 편익은 장시간에 걸쳐 투입되거나 발생하기 때문에 할인율을 적용하여 이 를 특정기간(일반적으로 현재년도)에 발생하는 것으로 환산하여 비교하게 되는데 이를 '현재 가치화'라고 한다. 각 사업의 편익-비용비는 현재 가치로 환산된 편익과 비 용으로 나타내는 것이 일반적이며 편익/비용 비율이 1.0 보다 크면 경제성이 있다고 판단된다.

$$
B / C \text { ratio }=P V \text { of } B / P V \text { of } C_{t}
$$

그러나 위 식에서 보듯이 편익/비용비율(B/C ratio)은 사업의 비용 1 단위당 편익이 얼마인가를 보여주는 것이 므로 자연히 소규모 사업이 상대적으로 높은 편익/비용 비율을 갖게 되는 경우가 많으며, 비용과 편익을 명확히
구분하기 어려울 때가 많다. 따라서 사업의 우선순위를 결정하는 데 있어 편익/비용 비율기준만으로 큰 의미가 있다 할 수 없다.

순현재가치(Net Present Value: NPV)는 현재가치로 환산된 장래의 연차별 순편익의 합계에서 초기 투자비용 및 현재가치로 환산된 장래의 연차별 비용의 합계를 뺀 값을 의미한다. $\mathrm{NPV}>0$ 이면 경제성이 있다고 판단한다.

$$
\mathrm{NPV}=-I_{o}+\sum_{n=1}^{N} \frac{N B_{n}}{(1+r)^{n}} \quad \mathrm{n}=1,2, \ldots \mathrm{N}
$$

여기서, I : 투자액, NB : 순편익, r : 사회적 할인율, $\mathrm{N}$ : 경제성 분석 기간

내부수익율(Internal Rate of Return: IRR)은 편익과 비용의 합계가 동일하게 되는 수준의 현재가치 할인율을 의미한다. 즉, 어떤 사업의 순현재가치의 값을 ' 0 '으로 하는 특정한 값의 할인율을 의미하는 것인데 내부수익율 이 시장이자율보다 높은 경우 혹은 공공사업에 대해 사 회적으로 용인할 수 있는 이자율보다 높게 나타나면 그 사업은 타당성이 있다고 평가한다.

$$
0=-I_{o}+\sum_{n=1}^{N} \frac{N B_{n}}{(1+\Pi)^{n}}
$$

여기서, I : 투자액, NB : 순편익, $\Pi$ : 내부수익률, $\mathrm{N}$ : 경제성 분석 기간

각 방안별 문제점을 간략하게 지적하면 우선, $\mathrm{B} / \mathrm{C}$ ratio와 IRR을 사용함에 있어 애매한 경우가 다소 있다. 구체적으로 $\mathrm{B} / \mathrm{C}$ ratio는 재투자 비용이 드는 사업을 평가 함에 있어 재투자 비용을 비용으로 산정할 것인지 혹은 음의 수익으로 산정할 것인지에 따라 다른 값을 가진다.

IRR은 사업규모가 다른 경우 IRR만으로는 우열을 가 리기 힘들다는 문제가 있으며, 사업간 상호 독립적이란 가정 하에 도출하는데, 만약 사업간 상호배타적인 경우, 즉 경쟁적 관계의 사업에서 다수의 IRR을 가지는 경우가 발생할 수 있는 문제점이 있다 IRR 및 $\mathrm{B} / \mathrm{C}$ ratio의 문제 점으로 인해 일반적으로 NPV가 우월하다고 알려져 있지 만, NPV 또한 예산상 제약이 있는 경우 한계가 있다.

대규모사업이 소규모사업에 비해 큰 순 현재가치가 발 생하게 되어 대규모사업이 통상 유리하게 평가되는데, 예산제약으로 인해 하나의 대규모 사업과 여러 개의 소 규모 사업 중 선택해야 하는 경우가 있을 경우, 이 경우 $\mathrm{NPV}$ 는 올바른 평가를 수행할 수 없다. 
결국 어떤 사업이 경제적 타당성의 유무판단기준으로 서 어느 한 기준에 전적으로 의존하는 것은 문제가 있음 을 인식해야 하며, 결론적으로 순현재가치, 내부수익률 및 편익/비용 비율 세 가지를 모두 적절하게 고려한 후 의사결정을 내리는 것이 타당하다.

\section{분석기간 및 사회적 할인율}

경제성 분석에 있어 비용과 편익은 모두 사회적 비용 및 편익으로 간주할 수 있는데, 일반적으로 공공 투자시 설의 경우 비용은 실질적으로 투자되어 사용된 비용을 계상하는 반면 편익은 회수 방법을 통한 실제 수익이 아 닌 사회적 편익을 기준으로 하게 된다 따라서 본 연구에 서도 먼저 비용 및 편익을 산정하고 이로부터 사업의 경 제성을 분석한다. 일반적으로 연구개발 사업 수행의 비 용과 편익은 어느 한 시점에만 발생하는 것이 아니라 보 통 수년 혹은 수십 년에 걸쳐 발생하므로, 사업 수행에 대한 경제성 분석은 특정한 시점을 일정하게 놓고 이루 어져야 한다. 그런데 통상 경제적 타당성 분석은 현재시 점에서 평가함이 원칙이 되고 있다

본 사업의 투자기간은 2013년부터 2022년까지이며, 편익은 2023년부터 2043년까지 발생하여, 2013년부터 2043 년까지가 경제성 분석 대상 기간이 된다. 현재가격 은 2010년 12 월을 기준으로 사업의 비용 및 편익에 적 용하고 본 사업은 그 성격상 비용이 초기에 집중 발생하 는 반면, 편익은 건설 후 장기간 동안 발생하기 때문에 분석기간 동안 예상되는 비용과 편익에 사회적 할인율을 적용하여 현재가치로 환산하여 평가한다.

사회적 할인율은 비용과 편익의 미래 흐름을 비교하기 위하여 사용되며 자원의 기회비용, 즉 투자 사업에 사용 된 자본이 다른 투자 사업에 사용되었을 경우 얻을 수 있는 수익을 추정하게 할 뿐 아니라 사람에 따라 혹은 사회에 따라 그리고 시대에 따라 다를 수 있는 시간의 객관적인 가치를 나타낸다.

할인율 개념의 적용에 있어서는 많은 이견이 있으나 특정 투자 사업이 정부에 의해 주도되는 경우에는 사회 적 할인율의 개념을 적용하고, 민간자본에 의해 추진되 는 경우에는 시장이자율에 근거한 재무적 할인율을 적용 하는 것이 일반적이다. 사회적 할인율은 통상 시장이자 율보다 낮은 수준으로 책정되는데, 그 이유는 사회적 할 인율을 사용하여 사업타당성을 평가하는 주체가 주로 정 부이며 정부로서는 미래사업의 중요성을 더 높게 평가하 어야 하기 때문이다.

이렇듯 적정 사회적 할인율을 추정하는 작업은 매우 복잡하므로 본 연구에서는 굳이 새롭게 추정하는 것보다 는 기존에 사용되고 있는 사회적 할인율을 적용하는 것
이 적용하기로 한다. 전력수급기본계획에서 사용하고 있 는 할인율은 $7.5 \%$ 가 적용되고 있지만, 한국개발연구원 (KDI)에서 제시하고 있는 사회적 할인율(2011년 12월 현재 $5.5 \%$ )을 이용하는 것이 더 효과적으로 볼 수 있다. 대부분의 국가는 투자사업의 특성에 따른 할인율을 자 국의 경제성장률, 물가상승률, 경제적 잠재능력 등을 고 려하여 개괄적인 방법으로 정부가 추정하여 사용하고 있 는데 일반적으로 개발도상국 사회간접자본의 경우는 $7-8 \%$ 이상, 선진국의 경우는 보통 5-6\% 수준을 적용하 고 있다. 본 경제성평가의 대상은 R\&D에 초점이 맞추어 져 있기 때문에, KISTEP의 예비타당성 평가에서 사용하 는 $5.5 \%$ 를 우선적으로 사용할 것이며, 따라서 본 연구에 서는 $\mathrm{KDI}$ 에서 사용하고 있는 『예비타당성조사 수행을 위한 일반지침』(제5판)에 의거하여 $5.5 \%$ 의 사회적 할인 율을 적용한다. 물론, 전력수급계획에서는 $7.5 \%$ 를 사용 하고 있지만, 본 사업에 R\&D가 포함되어 있고, 기술혁 신 주도형 설비(Innovation embodied facility)이기 때문 에 $5.5 \%$ 를 사용하였다.

\section{총 편익 추정결과}

3 개 각 부문(에너지생산, 고부가물질 창출, $\mathrm{CO}_{2}$ 저감) 의 편익추정 결과를 정리하면 Table 6과 같다. 에너지 생산으로 인해 발생하는 편익이 분석기간 내내 동일하다 고 가정한 근거는, 2026년 80억원, 2034년 80억원의 설 비재투자를 통하여, 설비의 노후화를 보강하고, 이에 따 라 발전량과 발전효율을 유지할 수 있다는 가정을 따랐 기 때문이다. 그럼에도 불구하고, 복합발전의 설비 노후 화에 대한 추가적인 연구를 통하여 보다 심도있는 고려 가 필요할 것으로 여겨진다.

고부가물질의 편익은 Table 1 의 편익을 보정하여 도출 하였다.

\section{경제성분석 결과}

비용-편익 분석에서 일반적으로 편익-비용 비율> 1 일 경우 경제적 타당성이 있는 것으로 판단된다. 본 사업의 경우 순현재가치는 0 보다 크며, 편익/비용 비율이 1.22로 1.0 을 상회한다(Table 7). 또한 IRR 역시 $10 \%>5.5 \%$ 이 므로 투자효율성이 확보되는 것으로 평가됨에 따라, 본 사업은 경제적 타당성을 확보하는 것으로 평가된다.

한편, 제작비와 운영비 등 비용부문에 대한 민감도 분 석을 위하여, 1) 제작비 및 운영비의 $10 \%$ 상승 시나리 오, 2) 제작비 및 운영비의 $20 \%$ 상승 시나리오에 대하여 경제성분석을 수행하여 보았다. 해당 결과는 Table 8 과 같이, 제작비 및 운영비의 $10 \%$ 상승시에는 $\mathrm{BC}$ ratio가 $1.14,20 \%$ 상승시에는 $\mathrm{BC}$ ratio가 1.06 을 보여, 경제성을 
Table 6. Estimation of benefits

(Unit: 100 million won)

\begin{tabular}{|c|c|c|c|c|c|c|c|c|}
\hline Year & $\begin{array}{l}\text { Benefit } \\
\text { (Energy) }\end{array}$ & $\begin{array}{l}\text { Present } \\
\text { benefit } \\
\text { (Energy) }\end{array}$ & $\begin{array}{c}\text { Benefit } \\
\text { (High quality } \\
\text { materials) }\end{array}$ & $\begin{array}{c}\text { Present } \\
\text { benefit } \\
\text { (High quality } \\
\text { materials) }\end{array}$ & $\begin{array}{l}\text { Benefit } \\
\left(\mathrm{CO}_{2}\right. \\
\text { reduction })\end{array}$ & $\begin{array}{c}\text { Present } \\
\text { benefit } \\
\left(\mathrm{CO}_{2}\right. \\
\text { reduction })\end{array}$ & $\begin{array}{c}\text { Total } \\
\text { benefit }\end{array}$ & $\begin{array}{c}\text { Total present } \\
\text { benefit }\end{array}$ \\
\hline \multicolumn{9}{|l|}{2014} \\
\hline \multicolumn{9}{|l|}{2015} \\
\hline \multicolumn{9}{|l|}{2016} \\
\hline \multicolumn{9}{|l|}{2017} \\
\hline \multicolumn{9}{|l|}{2018} \\
\hline 2019 & 27.3 & 18.8 & 40 & 28 & 0.4 & 0.3 & 68.2 & 46.9 \\
\hline 2020 & 27.3 & 17.8 & 40 & 26 & 0.4 & 0.3 & 68.2 & 44.4 \\
\hline 2021 & 27.3 & 16.9 & 40 & 25 & 0.4 & 0.3 & 68.2 & 42.1 \\
\hline 2022 & 27.3 & 16.0 & 40 & 24 & 0.4 & 0.2 & 68.2 & 39.9 \\
\hline 2023 & 27.3 & 15.1 & 40 & 22 & 0.4 & 0.2 & 68.2 & 37.8 \\
\hline 2024 & 27.3 & 14.4 & 40 & 21 & 0.4 & 0.2 & 68.2 & 35.9 \\
\hline 2025 & 27.3 & 13.6 & 40 & 20 & 0.4 & 0.2 & 68.2 & 34.0 \\
\hline 2026 & 27.3 & 12.9 & 40 & 19 & 0.4 & 0.2 & 68.2 & 32.2 \\
\hline 2027 & 27.3 & 12.2 & 40 & 18 & 0.4 & 0.2 & 68.2 & 30.5 \\
\hline 2028 & 27.3 & 11.6 & 40 & 17 & 0.4 & 0.2 & 68.2 & 28.9 \\
\hline 2029 & 27.3 & 11.0 & 40 & 16 & 0.4 & 0.2 & 68.2 & 27.4 \\
\hline 2030 & 27.3 & 10.4 & 40 & 15 & 0.4 & 0.2 & 68.2 & 26.0 \\
\hline 2031 & 27.3 & 9.9 & 40 & 15 & 0.4 & 0.2 & 68.2 & 24.7 \\
\hline 2032 & 27.3 & 9.4 & 40 & 14 & 0.4 & 0.1 & 68.2 & 23.4 \\
\hline 2033 & 27.3 & 8.9 & 40 & 13 & 0.4 & 0.1 & 68.2 & 22.1 \\
\hline 2034 & 27.3 & 8.4 & 40 & 12 & 0.4 & 0.1 & 68.2 & 21.0 \\
\hline 2035 & 27.3 & 8.0 & 40 & 12 & 0.4 & 0.1 & 68.2 & 19.9 \\
\hline 2036 & 27.3 & 7.6 & 40 & 11 & 0.4 & 0.1 & 68.2 & 18.9 \\
\hline 2037 & 27.3 & 7.2 & 40 & 11 & 0.4 & 0.1 & 68.2 & 17.9 \\
\hline 2038 & 27.3 & 6.8 & 40 & 10 & 0.4 & 0.1 & 68.2 & 16.9 \\
\hline 2039 & 27.3 & 6.4 & 40 & 10 & 0.4 & 0.1 & 68.2 & 16.1 \\
\hline 2040 & 27.3 & 6.1 & 40 & 9 & 0.4 & 0.1 & 68.2 & 15.2 \\
\hline 2041 & 27.3 & 5.8 & 40 & 9 & 0.4 & 0.1 & 68.2 & 14.4 \\
\hline 2042 & 27.3 & 5.5 & 40 & 8 & 0.4 & 0.1 & 68.2 & 13.7 \\
\hline 2043 & 27.3 & 5.2 & 40 & 8 & 0.4 & 0.1 & 68.2 & 13.0 \\
\hline Total & 682.5 & 265.6 & 971 & 386 & 10.5 & 4.1 & 1663.9 & 663.2 \\
\hline
\end{tabular}

Table 7. Results of benefit-cost analysis

\begin{tabular}{cccc}
\hline \hline Economic evaluation & Net present value (NPV) & BC ratio & Internal rate of return (IRR) \\
\hline Indicator figure & 12.19 billion won & 1.22 & $10 \%$ \\
\hline
\end{tabular}


Table 8. Sensitivity Test regarding cost

\begin{tabular}{cc}
\hline \hline Economic evaluation & BC ratio \\
\hline Main Result & 1.22 \\
\hline Scenario I $(10 \%$ increasing of cost $)$ & 1.14 \\
\hline Scenario II $(20 \%$ increasing of cost $)$ & 1.06 \\
\hline
\end{tabular}

확보하는 것으로 분석되었다. 물론, 전술한 바와 같이, 실 물옵션 등의 기법을 활용하여, 비용변화 등의 가변성을 고려한 경제성분석은 향후 과제로 남겨두도록 한다.

\section{결 론}

이 연구에서는 해양에너지 복합발전단지 사업의 경제 성 타당성을 평가하기 위해 KISTEP의 예비타당성 평가 와 $\mathrm{KDI}$ 에서 사용하는 사회적 할인율을 기준으로 추정하 였다. 본 연구개발사업의 정확한 경제적 당성 평가를 추 정하기 위해 합리적인 분석기간 설정, 적절한 비용과 편 익 추정 등을 통하여 종합적 경제성 분석을 수행하였다. 비용-편익 분석에서 일반적으로 편익-비용 비율> 1 일 경우 경제적 타당성이 있는 것으로 판단되는데, 본 사업 의 순현재가치는 0 보다 크며, 편익/비용 비율이 1.22 로 1.0 을 상회한다. IRR(내부 수익률)로 역시 $10 \%$ 로 기준 점인 $5.5 \%$ 를 상회하고 있는 것으로 나타나서 투자효율 성을 확보하는 것으로 나타났다. 따라서 본 사업은 경제 성 타당성을 확보하고 있다고 평가된다.

아울러 직접적인 경제적 편익(Tangible benefit) 중심 으로 편익을 추정하였으므로, 풍력 등 신재생에너지의 발전에 따른 환경개선효과, $\mathrm{CO}_{2}$ 추가 저감 효과, 풍력단 지의 관광단지화에 따른 지역경제 활성화 효과, 연구개발 성과의 확산 효과 등의 편익 부분은 별도로 산정하지 않 았다. 따라서 본 사업의 경제적 편익은 직접적인 편익을 추정한 것 외에, 앞에서 제기된 간접적 편익이 추가되어 도출된 수치보다 더 큰 편익을 나타낼 것으로 평가된다. 또한 앞으로 정산단가가 계속 오르는 추세이지만, 그 리드 패리티(Grid Parity)를 맞춘다는 전제하에 최근의 가격을 사용하였다. 1) 정산단가의 변동폭, 2) 풍력, 태 양광의 발전 효율( $15 \%, 20 \%), 3) \mathrm{CO}_{2}$ 저감양 규모 4) 바이오물질 생산 규모 등에 대하여 변동가능성(Volatility) 을 도입함으로써, 실물옵션(Real Option)을 이용한 경제 성평가를 추가적으로 수행해 볼만하다. 실물옵션 접근법
을 쓰면, 옵션가격을 포함하므로 $\mathrm{BC}$ 비율이 대폭 개선될 것으로 예상된다. 따라서 본 연구는 국내 해양에너지 복 합단지가 직접적 경제적 타당성을 확보하고 있는 것을 보여 주었으며, 향후 간접적 편익을 포함한 다양한 부분 에서 경제적 편익을 도출할 수 있을 것으로 기대된다. 하 지만 이는 방대한 작업량을 필요로 하기 때문에, 다음 연 구의 과제로 기대해 본다.

\section{사 사}

본 연구는 국토해양부 소관 연구개발사업인 "능동제어 형 조류발전 기술개발(20110171)"의 연구비를 지원받았다. 이 용길은 한국연구재단의 신진교수연구비(2012R1A1A1012649) 와 SSK(NRF-2012-S1A3A-2033860), 그리고 인하대학 교의 교내연구비의 지원을 받아 수행하였다.

\section{References}

Electric Power Statistics Information System, www.kpx.or.kr/ epsis/.

Hyundai Research Institute, 2009, Searching for New Growth Model, Solar PV cluster, HRI VIP reports, No.398, Seoul.

Ko, K.O., Jung, K.H., Lee, J.S. and Yoon, S.B., 2011, “The Need for Development of an Ocean Energy Generation Facility and Its Applications", The Journal of Korean Civil Engineers, Vol. 59, No. 12, pp. 29-36.

Korea Institute of Ocean Science and Technology (KIOST), 2011, Analysis of economic feasibility of ocean bio-energy development projects in Korea, KIOST, Seoul.

Lee, D. and Jeong, K., 2011, "Economic Evaluation of Alternatives for $\mathrm{CO}_{2}$ Reduction of Thermal Power Generation Companies using ROPM: Comparing CCS with RPS Implementation", Environmental and Resources Economics Review, Vol.20, No.1, pp.61-98.

Lee, S., 2011, Development of knowledge-based analysis system for R\&D feasibility Analysis, Korea Science and Technology Planning \& Evaluation (KISTEP), Seoul.

Ministry of Knowledge Economics (MKE) and Center for New and Renewable Energy (CNRE), 2011, Renewable Energy Portfolio Standards, CNRE, Seoul.

Moon, C., 2012, Energy and Environmental News+, April 9, No.233. 


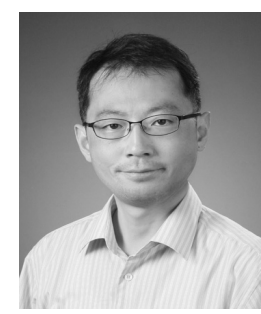

\section{이 용 길}

1997년 서울대학교 기계공학과 공학사 1999년 서울대학교 기술정책대학원 공 학석사

2006년 서울대학교 기술정책대학원 경 제학박사

현재 인하대학교 에너지자원공학과 조교수

(E-mail; leedomingo@inha.ac.kr)

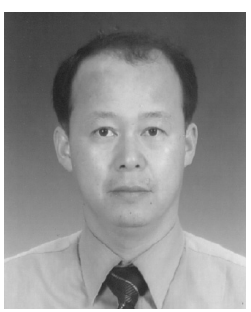

\section{박 우 선}

1984 서울대학교 공과대학 토목공학과 공학사

1986 한국과학기술원 토목공학과 공학 석사

1991 한국과학기술원 토목공학과 공학 박사

현재 한국해양과학기술원 연안개발- 에너지연구부 책임연구원 (E-mail; wspark@kiost.ac)

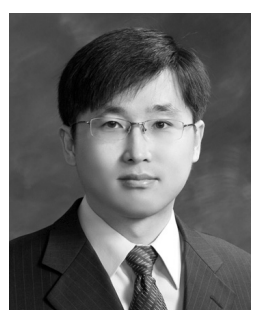

\section{고 진 환}

1995 한국과학기술원 기계공학과 공학 사

1997 한국과학기술원 기계공학과 공학 석사

2004 한국과학기술원 기계공학과 공학 박사

현재 한국해양과학기술원 연안개발- 에너지연구부 선임연구원 (E-mail; jhko@kiost.ac) 